\title{
Geometry and Geography: Racial Gerrymandering and the Voting Rights Act
}

While in form this is merely an act redefining metes and bounds . . . the inescapable human effect of this essay in geometry and geography is to despoil colored citizens, and only colored citizens, of their theretofore enjoyed voting rights.

$$
\text { -Justice Felix Frankfurter* }
$$

The Voting Rights Act Amendments of $1982,{ }^{1}$ in particular the amendments to section 2 of the Act, ${ }^{2}$ greatly facilitated legal challenges to racially discriminatory electoral structures. ${ }^{3}$ As a result, federal courts throughout the South are striking down at-large election systems as racially discriminatory. In their place, state and local governments will have to construct single-member districts. As this occurs, and as voting rights litigation continues to expand beyond the South, ${ }^{5}$ the legal focus will shift to questions of legislative districting and racial gerrymandering-the drawing of district lines in a manner that dilutes minority voting strength. This Note elucidates the meaning of the right created by section 2 in relation to the problem of racial gerrymandering.

Part I examines the text of section 2 in light of its legislative and judicial history and demonstrates the limited usefulness of section 2 in racial gerrymandering cases. Part II articulates a theory of equal electoral opportunity derived from the statute and proposes a new test for adjudicating claims of racial gerrymandering. Part III briefly compares this test with alternative approaches.

* Gomillion v. Lightfoot, 364 U.S. 339, 347 (1960).

1. Voting Rights Act Amendments of 1982, Pub. L. No. 97-205, 96 Stat. 131 (codified at 42 U.S.C. $\S \S 1971,1973$ to $1973 b b-1$ (1982)).

2. 42 U.S.C. $\$ 1973$ (1982). See Parker, The "Results" Test of Section 2 of the Voting Rights Act: Abandoning the Intent Standard, 69 VA. L. Rev. 715, 716 (1983) ("The new language of section 2 reinvigorates efforts of minority Americans to overcome discriminatory barriers to a meaningful vote."); see also Amended Voting Law Aids Blacks' Rights Actions, N.Y. Times, April 2, 1983, at 5, col. 1, 4 ("The most fundamental change affects Section 2 of the 1965 act . . . .").

3. According to Laughlin McDonald, Director of the Southern Regional Office of the American Civil Liberties Union, "There is no question that the law is having an immediate and dramatic impact." N.Y. Times, supra note 2 , at 5 , col. 1.

4. At-Large Voting is Losing in South, N.Y. Times, May 30, 1984, at 1, col. 1.

5. This is already occurring, as recent voting rights victories in Illinois attest. See Ketchum v. Byrne, Nos. 83-2044, 83-2065, 83-2126 (7th Cir. May 17, 1984) (Chicago City Council redistricting); Rybicki v. State Bd. of Elections, 574 F. Supp. 1082 (N.D. Ill. 1982) (three-judge court) (Illinois legislative redistricting). 


\section{Section 2: A Poverty of Theory}

As amended in 1982, section 2 of the Voting Rights Act prohibits any state practice "which results in" members of a racial or language minority $^{6}$ having "less opportunity than other members of the electorate to participate in the political process and to elect representatives of their choice." The meaning of these words, standing alone, is not immediately obvious. The focus on results, together with the concern about electing representatives and the implied norm of equality, might suggest that Congress was creating a right for minority groups to elect group members in proportion to the group's size. ${ }^{8}$ This interpretation, however, is disclaimed in the amendment's closing proviso: "[N]othing in this section establishes a right to have members of a protected class elected in numbers equal to their proportion in the population." The Senate Judiciary Committee's Report ${ }^{10}$ grounds this rejection of proportional representation, quite accurately, ${ }^{11}$ in the judicial history of racial vote dilution cases: "In case after case, the court expressly rejected proportional representation, and the dis-

6. Although the Voting Rights Act applies to other racial and language minorities, this Note will use blacks as the paradigmatic group.

7. The full text of $\S 2$, as amended, reads:

(a) No voting qualification or prerequisite to voting or standard, practice, or procedure shall be imposed or applied by any State or political subdivision in a manner which results in a denial or abridgement of the right of any citizen of the United States to vote on account of race or color, or in contravention of the guarantees set forth in section $1973 \mathrm{~b}(\mathrm{f})(2)$ of this title, as provided in subsection (b) of this section.

(b) A violation of subsection (a) of this section is established if, based on the totality of circumstances, it is shown that the political processes leading to nomination or election in the State or political subdivision are not equally open to participation by members of a class of citizens protected by subsection (a) of this section in that its members have less opportunity than other members of the electorate to participate in the political process and to elect representatives of their choice. The extent to which members of a protected class have been elected to office in the State or political subdivision is one circumstance which may be considered: Provided, That nothing in this section establishes a right to have members of a protected class elected in numbers equal to their proportion in the population.

42 U.S.C. § 1973 (1982).

8. The use of the term "proportional representation" by Congress and in this Note should be distinguished from its formal definition involving at-large elections and multiple parties. As Robert Dixon has noted, this "pure form has seldom been considered for America." R. Dixon, Democratic Representation: Reapportionment in LaW and Politics 49 (1968).

9. 42 U.S.C. $\& 1973(\mathrm{~b})$.

10. S. Rep. No. 417, 97th Cong., 2d Sess. reprinted in 1982 U.S. Code Cong. \& AD. News 177 [hereinafter cited as SENATE REPORT].

11. See, e.g., White v. Regester, 412 U.S. 755, 765-66 (1973) ("II]t is not enough that the racial group allegedly discriminated against has not had legislative seats in proportion to its voting potential."); Whitcomb v. Chavis, 403 U.S. 124, 149 (1971) (same); Marshall v. Edwards, 582 F.2d 927, 938 (5th Cir. 1978) ("Proportional racial representation, though attractive, is an abuse of the district court's equitable discretion."). But see City of Richmond v. United States, 422 U.S. 358, 370 (1975) (examining propriety of an annexation under $\S 5$ of the Act, the Court concluded that "a fairly designed ward plan in such circumstances would not only prevent the total exclusion of Negroes from membership on the council but would afford them representation reasonably equivalent to their political strength in the enlarged community"). 
claimer in Section 2 codifies this judicial disavowal."12 In addition to disclaiming any right to a particular electoral outcome, the statute explicitly emphasizes its concern with procedural fairness by protecting the opportunity of racial minorities to elect candidates of their choice.

Section 2's guarantee of procedural fairness extends well beyond the limited procedural protection of an intent standard, however. ${ }^{13}$ The 1982 amendment to section 2 represents the congressional response to the Supreme Court's decision in City of Mobile v. Bolden, ${ }^{\mathbf{1 4}}$ which required successful voting rights plaintiffs to prove discriminatory intent under the Fourteenth and Fifteenth Amendments, and under the original language of section $2 .{ }^{16}$ According to the Senate Report, Congress amended section 2 "to make clear that proof of discriminatory intent is not required to establish a violation of Section 2."16 The Report explains that under the

12. Senate RePort, supra note 10 , at 16 . The House Judiciary Committee also stressed this: "The proposed amendment does not create a right to proportional representation." H.R. REP. No. 227, 97th Cong., 1st Sess. 2 (1981) [hereinafter cited as House REPORT].

Electoral success of minority candidates, while not dispositive, remains relevant to a claim of vote dilution under section 2. The statute itself notes that "the extent to which members of a protected class have been elected to office . . . is one circumstance which may be considered . . . "42 U.S.C. $\S 1973$ (1982). The House Report refers to such proof as "highly relevant." House REPORT at 30. The judicial task of section 2 is, at a minimum, to apply a results test that does not degenerate into a requirement of proportional representation.

13. In the words of Professor Blumstein, an advocate of the intent standard in voting rights litigation, "[t]he norm of nondiscrimination is at bottom one of procedural regularity . . . [It] does not have an affirmative component." Blumstein, Defining and Proving Race Discrimination: Perspectives on the Purpose vs. Results Approach from the Voting Rights Act, 69 VA. L. REv. 633, 634, 652 (1983). This view of the intent standard is shared by a controlling majority of the Supreme Court. The two leading cases on the need to show discriminatory intent in Fourteenth and Fifteenth Amendment challenges, Washington v. Davis, 426 U.S. 229, 240 (1976) ("[T]he invidious quality of a law . . . must ultimately be traced to a racially discriminatory purpose."), and City of Mobile v. Bolden, 446 U.S. 55, 62 (1980) (plurality opinion) (facially neutral state action "violates the Fifteenth Amendment only if motivated by a discriminatory purpose"), reveal that the scrutiny is exclusively procedural; as long as the decisionmaking is free from invidious racial considerations, the outcomes are not relevant. Such a procedural focus is, as the plurality in Bolden admits, "wholly negative." Id. To the extent that intent may be inferred from objective factors, however, see, e.g., Rogers v. Lodge, 458 U.S. 613,618 (1982) ("discriminatory intent need not be proved by direct evidence"), it acquires substantive dimensions. To the same extent it ceases truly to be an intent standard.

14. 446 U.S. 55 (1980) (plurality opinion).

15. The plurality in Bolden wrote that "it is apparent that the language of $\S 2$ no more than elaborates upon that of the Fifteenth Amendment" which "prohibits only purposefully discriminatory denial or abridgement by government of the freedom to vote ...."Id. at 60,65 (footnote omitted).

Before the 1982 amendments, section 2 read: "No voting qualification or prerequisite to voting or standard, practice, or procedure shall be imposed or applied by any State or political subdivision to deny or abridge the right of any citizen of the United States to vote on account of race or color." Voting Rights Act of 1965, Pub. L. No. 89-110, 79 Stat. 437 (1965).

In Judge Goldberg's words, Bolden "completely changed the mode of assessing the legality of electoral schemes alleged to discriminate against a class of citizens . . . "Jones v. City of Lubbock, 640 F.2d 777, 777 (5th Cir. 1981) (Goldberg, J., specially concurring).

16. Senate RePort, supra note 10 , at 2 . The House Report was equally clear in its rejection of the intent standard: "The amendment clarifies the ambiguities which have arisen in the wake of the Bolden decision. It is intended by this clarification that proof of purpose or intent is not a prerequisite to establishing voting discrimination violations in Section 2 cases." HOUSE REPORT, supra note 12, at 2. 
results test, "the court would assess the impact of the challenged structure or practice on the basis of objective factors, rather than making a determination about the motivations which lay behind its adoption or maintenance."17 By examining the results of state action, section 2 guarantees minority voters substantive protection from vote dilution. But the guarantee of section 2-that there be no state-imposed, racially-based barriers to the political control of districts-is itself defined in terms of process, rather than substance, as in a specific electoral outcome. Thus, the section 2 right lies between the limited procedural guarantees of an intent standard and the substantive entitlements of proportional representation.

The Senate Report attempts to explain how courts should implement the results test, but the Report's guidance is of little use. Its theory of vote dilution is inadequate for the type of cases for which it was designed-cases involving at-large elections-and is largely irrelevant to racial gerrymandering cases. In defining the results test of section 2 the Report harks back to the pre-Bolden cases:

The proposed amendment to Section 2 of the Voting Rights Act is designed to restore the legal standard that governed voting discrimination cases prior to the Supreme Court's decision in Bolden. In preBolden cases plaintiffs could prevail by showing that a challenged election law or procedure, in the context of the total circumstances of the local electoral process, had the result of denying a racial or language minority an equal chance to participate in the electoral process. $^{18}$

The Senate Report identifies White $v$. Regester" as "the leading preBolden vote dilution case."20 In White the Supreme Court upheld, for the first time, a district court's finding that multimember districts "operated to dilute the voting strength of racial and ethnic minorities."21 Although the Court recited a number of findings made by the district court to support

17. Senate Report, supra note 10 , at 27. But see Blumstein, supra note 13, at 634 (arguing that "the substantive concept of 'discriminatory effect' stemming from neutral legislation is not only anomalous but also analytically bankrupt"); Perry, The Disproportionate Impact Theory of Racial Discrimination, 125 U. PA. L. REv. 540, 571 (1977) (disproportionate racial impact theory "is not applicable to legislative districting schemes").

Of course, plaintiffs retain the option of showing a violation under section 2 by proving intent. The Senate Report notes that plaintiffs "may establish discriminatory intent for purposes of this section, through direct or indirect circumstantial evidence, including the normal inferences to be drawn from the foreseeability of defendant's actions . . . SENATE REPORT, supra note 10, at $27 \mathrm{n} .108$.

18. SenAte RePORT, supra note 10, at 15-16. See also House REPORT, supra note 12, at 29 ("Congress intends to restore the pre-Bolden understanding of the proper legal standard . . . .").

19. 412 U.S. 755 (1973).

20. Senate RePoRt, supra note 10 , at 2.

21. 412 U.S. at 759. 


\section{Racial Gerrymandering}

its invalidation of the two Texas voting systems, ${ }^{22}$ attorneys Blacksher and Menefee correctly point out that the Court "once again avoided systematic analysis of the minority vote dilution phenomenon. . .".23 More generally, Professor Hartman has noted that "[p]roponents of amended section 2 were far too sanguine about the clarity of the pre-Bolden results test and the guidance pre-Bolden case law would give courts applying the statutory results test." 24

Criteria emerge from White; a jurisprudence of vote dilution does not. The Fifth Circuit, sitting en banc in Zimmer $v$. McKeithen, ${ }^{25}$ culled various criteria for vote dilution from White, and it is from Zimmer that the Senate Judiciary Committee derived its list of factors that may be used to "establish a violation."28 This list includes criteria that go to the electoral structure, such as the use of majority vote requirements or discriminatory slating processes, as well as to the social context, such as abiding effects of discrimination, polarized voting, and racial campaign tactics. ${ }^{27}$ A showing

22. With respect to Dallas County, the district court found a "history of official racial discrimination in Texas, which at times touched the right of Negroes to register and vote and to participate in the democratic processes." 412 U.S. at 766. It also found a majority vote requirement in the primaries, the use of numbered posts (which "enhanced the opportunity for racial discrimination"), and the use of "racial campaign tactics." Id. at 766-67. "More fundamentally, [the district court] found that since Reconstruction days, there have been only two Negroes in the Dallas County delegation to the Texas House of Representatives...." Id. at 766.

The Court found that the Mexican-American community in Bexar County "suffered from and continues to suffer from, the results and effects of invidious discrimination and treatment in the fields of education, employment, economics, health, politics, and others." " 412 U.S. at 768, quoting Graves v. Barnes, 343 F. Supp. 704, 728 (W.D. Tex. 1972). It recognized the "residual impact of this history" in the very low voter registration rates and in the fact that "only five Mexican-Americans since 1880 have served in the Texas Legislature from Bexar County." 412 U.S. at 767-69.

23. Blacksher \& Menefee, From Reynolds v. Sims to City of Mobile v. Bolden: Have the White Suburbs Commandeered the Fifteenth Amendment?, 34 Hastings L.J. 1, 22 (1982). They continue: "Indeed, the meaning of the Court's unanimity in the White $v$. Regester ruling against the two Texas multimember districts is unclear." Id.

24. Hartman, Racial Vote Dilution and Separation of Powers: An Exploration of the Conflict Between the Judicial "Intent" and the Legislative "Results" Standards, 50 Gro. WASH. L. REV. 689, 732 (1982).

25. 485 F.2d 1297, 1305 (5th Cir. 1973) (en banc), aff d on other grounds sub nom. East Carroll Parish School Bd. v. Marshall, 424 U.S. 636 (1976).

The criteria were refined and distilled somewhat by the Fifth Circuit:

[W] here a minority can demonstrate a lack of access to the process of slating candidates, the unresponsiveness of legislators to their particularized interest, a tenuous state policy underlying the preference for multi-member or at-large districting, or that the existence of past discrimination in general precludes the effective participation in the election system, a strong case is made. Such proof is enhanced by a showing of the existence of large districts, majority vote requirements, anti-single shot voting provisions and the lack of provision for at-large candidates running from particular geographical subdistricts. The fact of dilution is established upon proof of the existence of an aggregate of these factors.

485 F.2d at 1305 (footnotes omitted).

26. SENATE REPORT, supra note 10 , at 28 \& n.113. In setting forth the relevant factors, the Report explicitly acknowledges reliance on Zimmer: "These factors are derived from the analytical framework used by the Supreme Court in White, as articulated in Zimmer." Id. at 28 n.113.

27. The Senate Report suggests that the following factors are indicative of vote dilution:

1. the extent of any history of official discrimination in the state or political subdivision that 
under these factors is sufficient to establish a section 2 violation. The Senate Committee notes, however, that "[w]hile these enumerated factors will often be the most relevant ones, in some cases other factors will be indicative of the alleged dilution." any particular number of factors be proved, or that a majority of them point one way or the other." ${ }^{28}$ Nevertheless, the Zimmer factors are central to the Committee's discussion of section 2's application. ${ }^{30}$

The Zimmer factors thus provide a second source of guidance for interpreting the amended text of section 2. Unfortunately, they are no more helpful than the confused case law from which they emerge. First, there is some debate about whether Zimmer itself speaks in terms of results or intent. The Fifth Circuit in Nevett v. Sides" held that the "Zimmer criteria go to the issue of intentional discrimination, . . . because they would be irrelevant if motivation were not an issue."32 Even if not irrelevant, it is certainly the case that the Zimmer criteria "are merely causes or symptoms of [racial vote] dilution and not the most direct and reliable means of measuring it."ss

The second problem with Zimmer follows from the tentativeness of the

touched the right of the members of the minority group to register, to vote, or otherwise to participate in the democratic process;

2. the extent to which voting in the elections of the state or political subdivision is racially polarized;

3. the extent to which the state or political subdivision has used unusually large election districts, majority vote requirements, anti-single shot provisions, or other voting practices or procedures that may enhance the opportunity for discrimination against the minority group; 4. if there is a candidate slating process, whether the members of the minority group have been denied access to that process;

5. the extent to which members of the minority group in the state or political subdivision bear the effects of discrimination in such areas as education, employment and health, which hinder their ability to participate effectively in the political process;

6. whether political campaigns have been characterized by overt or subtle racial appeals;

7. the extent to which members of the minority group have been elected to public office in the jurisdiction.

Additional factors that in some cases have had probative value as part of plaintiffs' evidence

to establish a violation are:

whether there is a significant lack of responsiveness on the part of elected officials to the particularized needs of the members of the minority group.

whether the policy underlying the state or political subdivision's use of such voting qualification, prerequisite to voting, or standard, practice or procedure is tenuous. While these enumerated factors will often be the most relevant ones, in some cases other factors will be indicative of the alleged dilution.

Id. at 28-29 (footnotes omitted).

28. Id. at 29 .

29. Id.

30. For the Committee's discussion of the operation of that section, see id. at 27-31.

31. 571 F.2d 209 (5th Cir. 1978), cert. denied, 446 U.S. 951 (1980).

32. 571 F.2d at 222 . The Supreme Court apparently adopted this view of Zimmer when it upheld a district court's finding of intentional vote dilution which "[f]or the most part . . . dealt with the evidence in terms of the factors set out in Zimmer and its progeny . . . " Rogers v. Lodge, 458 U.S. 613,622 (1982).

33. Blacksher \& Menefee, supra note 23 , at 57. 
relationship between factors and inquiry. In a special concurrence in Nevett, Judge Wisdom explained that when a court is confronted with a test consisting of an aggregate of factors, the decision often involves a weighing and balancing of divergent inferences, and "the case turns on the attitude of the trial judge and the appellate judges . . . ."34 With such an elusive standard, judicial discretion is at a maximum and outcomes are likely to be inconsistent. ${ }^{35}$

These limitations are problems with Zimmer per se. The most severe limitation of Ziminer, however, is that its factors were conceived and developed solely in response to situations involving at-large election systems, which submerge concentrations of minority voters sufficient to elect representatives within larger, majority white, multimember districts. ${ }^{36}$ The legislative history of section 2 suffers from the same narrow focus. ${ }^{37}$ This concentration on at-large systems accurately reflects the course of voting rights litigation over the past decade, ${ }^{38}$ but is poorly suited to the emerging focus on racial gerrymandering.

As defined by Robert Dixon, "[g]errymandering is simply discriminatory districting which operates unfairly to inflate the political strength of one group and deflate that of another."39 The impact of gerrymandering

34. 571 F.2d at 233 (Wisdom, J., specially concurring). Blacksher and Menefee also suggest this problem: "Most of the cases concluding under the White-Zimmer guidelines that at-large schemes were constitutional cannot be distinguished analytically from those reaching a contrary result on any basis other than the varying personal political views of the trial and appellate judges who decided them." Blacksher \& Menefee, supra note 23, at 43.

At least one commentator has added the complaint that "the only manageable parameter" in Zimmer is the proportion of minorities elected, thus amounting to "an implicit recognition of a right to proportional representation." Goulder, The Reconstructed Right to Vote: Neutral Principles and Minority' Representation, 9 CAP. U.L. REV. 31, 79 (1979).

35. Cf. Note, Making the Violation Fit the Remedy: The Intent Standard and Equal Protection Law, 92 YALE L.J. 328, 349 (1982) ("Rogers [v. Lodge] . . . strongly suggests that the Fifth Circuit's Zimmer 7. McKeithen factors should be regarded as the central indicia of discriminatory intent, yet provides no explanation of why these factors were held to be insufficient in Bolden.") (footnotes omitted).

This judicial discretion accentuates what many consider already troubling federalism concerns. Federal interference is most offensive, it could be argued, if it appears random, unpredictable, and arbitrary.

36. See Zimmer v. McKeithen, 485 F.2d 1297, 1300-02; White v. Regester, 412 U.S. 755 (1973); Whitcomb v. Chavis, 403 U.S. 124 (1971).

In September, 1983, a three-judge court in Louisiana applying section 2 to a racial gerrymandering challenge explained that: "Dilution jurisprudence has evolved primarily in the context of constitutional challenges to state at-large or multimember districts." Major v. Treen, 574 F. Supp. 325, 342 n.22 (E.D. La. 1983).

37. Significantly, in the Judiciary Committee's discussion of the law prior to Bolden (SENATE REPORT, supra note 10 , at 19-24), the only reference to a racial gerrymandering case was in a footnote to explain that in Wright v. Rockefeller, 376 U.S. 52 (1964), the plaintiffs had failed to allege discriminatory impact. SENATE REPORT, supra note 10 , at 19 n.60. It is, however, quite beyond contention that section 2 is intended to apply to legislative districting challenges as well as to atlarge election systems. Both the House RePORT, supra note 12, at 30-31 and the SenATE RePORT, supra note 10 , at 12 n. 31 , explicitly refer to discriminatory districting.

38. See N.Y. Times, supra note 4, at B7, col. 6.

39. Dixon, The Court, The People, and "One Man, One Vote," in Reapportionment in the 
has long been recognized by both courts and commentators. In a nonracial context, the Supreme Court noted that "[d]istrict lines are rarely neutral phenomena." ${ }^{30}$ Racial gerrymandering concerns ward boundaries that pack minorities into a minimum number of wards, or disperse minority voters into surrounding white districts. ${ }^{41}$ The Fifth Circuit has underscored the importance of the issue: "The most crucial and precise instrument of the ... denial of the black minority's equal access to political participation ... remains the gerrymander of precinct lines . . ."12 Similarly, the United States Commission on Civil Rights found that " $[w]$ hen political officials are elected by districts, the opportunities for minority representation depend greatly on the way district lines are drawn."43 In a polarized polity, all districting allocates electoral power by dividing some groups and uniting others.

Consider, for example, the 1981 redistricting of the Chicago aldermanic district. The map proposed by the city combined the classic gerrymander techniques of "fracturing"-slicing off significant portions of the black community into white majority wards-and "packing"-concentrating the black population into a few wards-in order to reduce the number of black majority districts from 19 to $17 .{ }^{44}$ Without violating the independent constitutional mandate of equipopulous districts, ${ }^{45}$ plaintiffs proposed alternative maps with 20,21 , and 22 black majority districts. ${ }^{40}$ The opportunities for gerrymandering are obviously legion.

To be sure, the courts have not been silent on the extension of Zimmer

1970's, at 29 (N. Polsby ed. 1971). In this Note, "discriminatory districting" refers only to the manipulation of district lines, and not to the use of biased structures such as at-large election systems.

40. Gaffney v. Cummings, 412 U.S. 735, 753 (1973).

41. See, e.g., Gingles v. Edmisten, No. 81-803-GIV-5, slip op. at 18 (E.D.N.C. Jan. 27, 1984) (three-judge court) ("Vote dilution in the White $v$. Regester sense may result from the fracturing into several single-member districts as well as from the submergence in one multi-member district of black voter concentrations . . . ."). See generally, Parker, Counly Redistricting in Mississippi: Case Studies in Racial Gerrymandering, 44 Miss. L.J. 391 (1973) (describing classic forms of racial gerrymandering).

42. Robinson v. Commissioners Court, 505 F.2d 674, 679 (5th Cir. 1974); see also Howard v. Adams County Bd. of Supervisors, 453 F.2d 455, 457 (5th Cir.) ("The gerrymander is as great a threat to equality of representation as malapportionment."), cert. denied, 407 U.S. 925 (1972).

43. U. S. Comm'n on Civil Rights, The Voting Rights ACt: Unfulfilled Goals 39 (1981).

44. Ketchum v. City Council, No. 82-C-4085, slip op. at 4101-03 (N.D. Ill. Dec. 21. 1982), affd in part, rev'd in part, and remanded sub nom. Ketchum v. Byrne, Nos. 83-2044, 83-2065, 83-2126 (7th Cir. May 17, 1984). Since Chicago was $39.8 \%$ black in 1980, Bureau of Census, U.S. DeP'T of Commerce, Statistical ABstract of the United States: 1984, at 28 (1984) [hereinafter Statistical ABSTRACT], at least 20 of the 50 city council districts should have contained black supermajorities. The cohesiveness of the black community, see infra note 82 , makes it clear that there were no feasibility limits.

45. Reynolds v. Sims, 377 U.S. 533, 568 (1964).

46. Brief for the Lawyers' Committee for Civil Rights Under Law as Amicus Curiae at 31, Ketchum v. Byrne, Nos. 83-2044, 83-2065, 83-2126 (7th Cir. May 17, 1984) (on file with the Yale Law Journal). 
to racial gerrymandering. The Fifth Gircuit explained that the "tests should be the same whether the right to an equally effective vote is denied by drawing district lines or erasing them . . . ."47 But while the manipulation of single-member district lines, like the use of at-large systems, can have discriminatory results, these two electoral structures function to dilute minority strength in distinct ways. In addition to the general submersion of minority voters in large white concentrations, at-large systems frequently use techniques such as majority-vote requirements, anti-single shot voting provisions, and numbered places ${ }^{48}$ in the context of multimember districts to accentuate the winner-take-all characteristics of majoritarian voting. As a result, when an at-large scheme operates discriminatorily, minority voters are "effectively removed from the political processes,"49 and the denial of access is complete. A racial gerrymander, by contrast, is more likely to reduce, rather than deny, electoral opportunity. Racial gerrymandering is consequently more difficult to detect.

Some of the Zimmer factors-those which focus on electoral structure-simply have no relation to single-member districting. ${ }^{\circ 0}$ The remaining factors are important to establish the social context, but, since they are independent of any particular district configuration, they can provide no insight into the relative merits of various districting plans. The Fifth Circuit apparently recognized this in Kirksey $v$. Board of Supervisors. ${ }^{51}$ In Kirksey, the court used the Zimmer factors to show that blacks were historically denied access to the political process in Hinds County, Mississippi. ${ }^{62}$ In order to determine whether the particular districting scheme at issue had "the effect of perpetuating the denial of access," Kirksey court left Zimmer behind and examined the placement of particular district lines with respect to the black community. ${ }^{64}$ This type of

47. Nevett v. Sides, 571 F.2d 209, 219 (5th Cir. 1978), cert denied, 446 U.S. 951 (1980). See also Kirksey v. Board of Supervisors, 554 F.2d 139, 143 (5th Gir.) (en banc) ("[T]hese standards . . . have equal application to redistricting schemes making use of single-member districts . . .."), cert. denied, 434 U.S. 968 (1977).

48. Anti-single shot voting provisions prohibit voters in multimember districts from targeting all their votes on a single candidate. Numbered places ensure that candidates are paired (or grouped) in head-to-head contests.

49. White v. Regester, 412 U.S. 755, 769 (1973) (quoting Graves v. Barnes, 343 F. Supp. 704, 733 (W.D. Tex. 1972)).

50. As Frank Parker explains, "[I]n a challenge to a discriminatory redistricting plan which employs single-member districts, factors such as majority vote requirements, anti-single-shot provisions, and the lack of a district residency requirement would be irrelevant, since those are characteristics of multimember district and at-large election schemes." Parker, supra note 2, at 763.

51. 554 F.2d 139 (5th Cir.) (en banc), cert. denied, 434 U.S. 968 (1977).

52. Id. at $143-46$.

53. Id. at 148 .

54. Id. at 148-51. The court found that "[b]y fragmenting a geographically concentrated but substantial black minority in a community where bloc voting has been a way of political life the plan will cancel or minimize the voting strength of the black minority . . . Id. at 151 .

A similar analysis was recently used by a three-judge court in Louisiana to invalidate, under $\S 2$, 
straightforward observational analysis, while relatively unproblematic in a single Mississippi county with only five districts, is far more difficult to apply to a large urban ward map or a state legislature's districting plan. These latter instances, where the number of intersections between district boundaries and the minority communities, and thus the number of possible districting permutations, is great, demand a more sophisticated method of analysis. More generally, in cases of racial gerrymandering, where the denial of access is unlikely to be complete, ${ }^{\text {s5 }}$ the Zimmer factors are unable to distinguish between alternative districting plans. ${ }^{.6}$ Use of the Zimmer factors is simply not an effective way to evaluate claims of racial gerrymandering.

The central limitation of section 2 , then, is that in failing to articulate a theory of equal electoral opportunity, it ultimately offers little guidance for those courts seeking to depart from the Zimmer factors. In the following section, this Note will elaborate such a theory consistent with the language of section $2 .{ }^{57}$

\section{Deriving a Standard for Racial Gerrymandering}

\section{A. A Group Theory of Equal Electoral Opportunity}

Section 2, as amended, creates a right to equal electoral opportunity, a right for "members of a [protected] class" to have equal "opportunity . . . to elect representatives of their choice." 138 Although the reference to group "members" could prompt an individualistic interpretation, both legislative and judicial history suggest that section 2 creates group rights reaching far beyond the rights of individuals to register and to vote.

The power to elect representatives is necessarily a group power. ${ }^{68}$ The

an act establishing the boundaries between two congressional districts. The court found that the boundary line "slices through the City's traditional political subunit, the ward, in a racially selective manner, leaving intact predominantly white wards while carving up those densely populated by blacks." Major v. Treen, 574 F. Supp. 325, 353 (E.D. La. 1983). In this case, however, the court integrated the evidence of racial gerrymandering into the Zimmer aggregate of factors. Id. at 352.

55. See supra text accompanying notes 49-50.

56. When evaluating an at-large system, a court asks whether that system dilutes votes in comparison to a potential single-member districting plan. The court does not compare alternative singlemember plans. See Note, Group Representation and Race-Conscious Apportionment: The Roles of States and the Federal Courts, 91 HARv. L. REv. 1847, 1861 (1978) ("Without a standard by which to measure a particular single-member plan, the White $v$. Regester [Zimmer] test cannot be applied to single-member districting.").

57. Because it operates at a higher level of generality than the Zimmer-Senate factors, the theoretical treatment that follows could apply with equal force to problems of at-large systems. The legislative history speaks relatively clearly with respect to at-large elections, however, and thus provides less support for departing from Zimmer in that area.

58. 42 U.S.C. \& 1973 (1982). See also Ketchum v. Byrne, Nos. 83-2044, 83-2065, 83-2126, slip op. at 38 (7th Cir. May 17, 1984) ("The mandate of section 2 of the Voting Rights Act is that minorities must be given a reasonable and fair chance to elect candidates of their choice.").

59. See Hartman, supra note 24, at 691 ("Claims of racial vote dilution arise when voters are not 
Senate Report defines the "basic dilution principle" as that situation in which a "favored group has full voting strength . . . [while] groups not in favor have their votes discounted." "60 The case law supports this notion of a group right. As stated in Kirksey, the Zimmer factors, which must be consistent with any coherent theory of section $2,{ }^{61}$ "are more relevant to whether a group has input into the political decision-making process than to whether a particular individual is free to vote."

Racial groupings will not, however, always be relevant in politics. In fact, the ambition behind the Voting Rights Act is to create a society where race is a wholly irrelevant political criterion. ${ }^{63}$ Racially polarized politics distinguishes the real from the ideal. Where race is a salient political factor, group members will act substantially in concert, racial groupings will have an independent political existence, and a theory of racial group disadvantaging can make sense. Where race is not relevant and racial bloc voting does not occur, electoral cleavage lines would cross rather than track racial lines. Thus, racially polarized voting "will ordinarily be the keystone of a dilution case." 64 For, as the Supreme Court noted in Rogers v. Lodge, "without bloc voting the minority candidates would not lose elections solely because of their race."'65 Thus, racial polarization is a necessary prerequisite to any claim of vote dilution under section $2 .{ }^{68}$

fungible but are divided sharply into racial or ethnic groups of differing strength whose members . . . vote as a bloc.").

60. SenAte RePort, supra note 10, at 19 (quoting Reynolds v. Sims, 377 U.S. 533, 555 n.29 (1964)).

61. They must be consistent with any theory of section 2 since they remain an alternative means for enforcing it.

62. Kirksey v. Board of Supervisors, 554 F.2d 139, 143 n.10 (5th Cir.) (en banc), cert. denied, 434 U.S. 968 (1977). See also Chapman v. Meier, 420 U.S. 1, 17 (1975) ("There must be evidence that the group has been denied access to the political process equal to the access of other groups.").

63. See South Carolina v. Katzenbach, 383 U.S. 301, 308 (1966) ("The Voting Rights Act was designed by Congress to banish the blight of racial discrimination in voting, which has infected the electoral process in parts of our country for nearly a century.").

64. United States v. Marengo County Comm'n., 731 F.2d 1546, 1566 (11th Gir. 1984); Cf. Nevett v. Sides, 571 F.2d 209, 223 (5th Cir. 1978) (when speaking of vote dilution, "the existence of such discrimination presupposes racially polarized voting in the electorate"), cert. denied, 446 U.S. 951 (1980).

65. 458 U.S. 613, 623 (1982). Accord Hale County v. United States, 496 F.Supp. 1206, 1214-15 (D.D.C. 1980); Hartman, supra note 24 , at 736.

66. This limiting principle can be found in both the judicial and legislative histories of section 2 . See, e.g., Cross v. Baxter, 604 F.2d 875, 880 n.8 (5th Cir. 1979) ("Evidence of racial polarization in voting has been held to be a prerequisite to a voting dilution challenge."); SENATE REPORT, supra note 10 , at 33 .

Racial polarization appears to be widespread. The authors of one seventeen-year study of the five largest southern cities concluded that "voting in large Southern cities tends to follow racial lines," especially when blacks run as candidates. Murray \& Vedlitz, Racial Voting Patterns in the South, 439 AnNals 29, 33 (1978).

Racial polarization is not, however, to be assumed. According to the Senate Report, "[t]he results test makes no assumptions one way or the olher about the role of racial political considerations in a particular community." SenATE RePORT, supra note 10, at 34 (emphasis in original). For the purposes of litigation under section 2, whether racial polarization exists in a given polity must be estab- 
The existence in a case of sufficient racial polarization ${ }^{67}$ allows the concept of equal electoral opportunity to be analyzed in group terms. Where groups of differing size are involved, equality translates into proportionality. If the opportunity of groups to elect representatives of their choice were disproportionate to group size, members of differing size groups would possess unequal electoral power. In a racially polarized polity divided into single-member districts, a racial minority will be able to elect representatives only if it constitutes a controlling majority in certain districts. ${ }^{68}$ Where blacks are a numerical minority, racial bloc voting means that blacks must back either a white-supported candidate or a loser. ${ }^{69}$

\section{B. A New Standard For Racial Gerrymandering}

The group theory of equal opportunity leads to a straightforward standard for measuring and remedying vote dilution in a racially polarized multi-ward polity: Minority groups must have the ability to control the elections in as near to a proportional number of wards as is feasible. Both "ability to control" and "feasible" require further definition.

In the context of single-member districting, the phrase "ability to control" captures the essential tension of section 2 created by substantive guarantees of procedurally defined outcomes. To make electoral opportu-

lished, as federal courts have often done, on a case-by-case basis. The Senate Report makes it clear that the burden of proving racial polarization rests with the plaintiffs. Id. at 34 . Statistical evidence of racial bloc voting is of primary importance in establishing the requisite racial polarization. To support the statistical evidence, plaintiffs could also present evidence of some of the Zimmer-Senate factors: racial appeals in past campaigns, a history of official discrimination in voting or politics, present effects of past discrimination. Id. at 28-29.

Racial polarization should be seen as an attribute not of a single election, but rather of a polity viewed over time. The concern is necessarily temporal and the analysis historical because the evil to be avoided is the subordination of minority groups in American politics, not the defeat of individuals in particular electoral contests. Cf. Fiss, Groups and the Equal Protection Clause, 5 PHIL. \& PuB. Aff. 107,151 n.67 (1976) (concern about caste effects involves "[t]he critical temporal issue . . . of duration").

67. It is important to recognize that racial polarization is a question of degree. At some point along the continuum from absolute polarization to nonpolarization, the degree of polarity becomes insufficient to support a claim of racial vote dilution. Similarly, lesser variations from the absolute may require some scaling of the remedy. In either case, however, the determination is fact-specific, and must be committed to case-by-case analysis.

68. See Major v. Treen, 574 F. Supp. 325, 339 (E.D. La. 1983) ("Racial bloc voting, in the context of an electoral structure wherein the number of votes needed for election exceeds the number of black voters, substantially diminishes the opportunity for black voters to elect the candidate of their choice."). See also SENATE REPORT, supra note 10, at 33 ("In the context of . . . racial bloc voting ... a particular election method can deny minority voters equal opportunity.").

69. See Note, United Jewish Organizations v. Carey and the Need to Recognize Aggregate Voting Rights, 87 Yale L.J. 571, 574 (1978) (in certain contexts, "racial bloc voting ensures that a nonwhite minority will never, in fact, influence any election"). See also Seamon v. Upham, No. P-81-49-CA, slip op. at 4-5, (E.D. Tex. Feb. 1984) (three-judge court) (Steger, J., dissenting) (the court's holding limits minority citizens to deciding "between candidates previously selected by the white majorities of the competing political parties").

Moreover, where politics is racially polarized, minority group members will be able to influence representatives only if they can elect them. 
nity equal, all racially-based handicaps-the legacies of past and present purposeful and societal discrimination and the electoral structures that exploit them-must be compensated for. ${ }^{70}$ The courts have repeatedly held that the lower levels of minority registration and turnout ${ }^{71}$ are attributable to past discrimination. ${ }^{72}$ Consequently, minority control of districts requires a "supermajority"-more than a simple population majority. ${ }^{73}$ This fact has long been accepted by courts remedying at-large election systems or redrawing district lines, and most courts ${ }^{74}$ have adopted a benchmark supermajority figure of 65 percent population (60 percent voting age population) $)^{75}$ in defining "safe" districts.

Section 2, however, is concerned with opportunity. Thus while safe districts may be required, ${ }^{76}$ guaranteed districts are prohibited. Courts have been remarkably successful at treading the fine line between the two. ${ }^{77}$ Under the Voting Rights Act, the ideal supermajority level is that at

70. By providing the link to past and present discrimination, racial polarization becomes the normative premise for remedial action. Absent discrimination, race would be politically irrelevant, and voters would be seen as neither black nor white, but just as voters. See Marshall, A Comment on the Nondiscrimination Principle in a "Nation of Minorities", 93 YALE L.J. 1006, 1009 (1984) ("It is in the nature of racial discrimination that it ignores individuals' other traits, and treats their race as the overriding quality of all members of the racial group.").

71. Sep Statistical. ABStRAct, supra note 44, at 265 (comparative 1980 registration rates: $68.4 \%$ white, $60.0 \%$ black, $36.3 \%$ Hispanic; turnout: $60.9 \%$ white, $50.5 \%$ black, $29.9 \%$ Hispanic).

72. See, e.g., Major v. Treen, 574 F. Supp. 325, 341 (E.D. La. 1983) ("[T]he residual effects of past discrimination still impede blacks from registering, voting or seeking elective office in Orleans Parish."); Hale County v. United States, 496 F. Supp. 1206, 1213-14, 1217 (D.D.C. 1980) (threejudge court) (the evidence presented "linked low black voter turnout to the many years of social, economic, and political discrimination"); see aiso Kirksey v. Board of Supervisors, 554 F.2d 139, 145 n.13 (5th Cir.) (en banc) ("Failure to register may be, for example, a residual effect of past nonaccess, or of disproportionate education, employment, income level or living conditions."), cert. denied, 434 U.S. 968 (1977).

73. As the Seventh Circuit recently noted: "The test of an effective majority is that share of the population required to provide minorities with 'a realistic opportunity to elect officials of their choice ... " Ketchum v. Byrne, Nos. 83-2044, 83-2065, 83-2126, slip op. at 24 (7th Cir. May 17, 1984).

74. See United Jewish Orgs. v. Carey, 430 U.S. 144, 164 (1977) (White, J.) ("[A] substantial nonwhite population majority -in the vicinity of $65 \%$-would be required to achieve a nonwhite majority of eligible voters."); Rybicki v. State Bd. of Elections, 574 F. Supp. 1147, 1152 (N.D. Ill. 1983) (three-judge court) (" $65 \%$ is a generally accepted threshold for providing an opportunity for minorities to elect a representative of their choice"); Mississippi v. United States, 490 F. Supp. 569, 575 (D.D.C. 1979) (three-judge court) ("[B]arring exceptional circumstances . . . a district should contain a black population of at least 65 percent or a black VAP [voting age population] of at least 60 percent to provide black voters with an opportunity to elect a candidate of their choice."), affd mem., 444 U.S. 1050 (1980).

75. Supermajorities also make sense because, compared to other groups, a smaller percentage of minority populations is of voting age. See Statistical ABSTRACT, supra note 44, at 36, $265(73.1 \%$ of whites of voting age; $61.9 \%$ of blacks and $56.1 \%$ of Hispanics).

76. But see Howard \& Howard, The Dilemma of the Voting Rights Act-Recognizing the Emerging Political Equality Norm, 83 Colum. L. REv. 1615, 1656-62 (1983) (suggesting alternatives to safe districting).

77. Some have suggested that this line is nonexistent. See Fiss, supra note 66, at 154 ("A just political process would be one in which blacks would have 'more' of a voice than they in fact do, but not necessarily one in which they would 'win.' In a sense there is a remedial lacuna; a pure process claim cannot determine substantive outcomes."). 
which a minority-supported candidate's defeat could not be attributable to his or her race or the race of his or her supporters: The Act stops short of shielding candidates from defeat on the merits, or because of inadequate organization, campaigning, or appeal. ${ }^{78}$ Minority candidates have frequently been elected from redrawn districts, but despite compensation for the statistical disparities, their success has been far from automatic.78 Thus, giving minority voters the ability to control districts under the standard proposed here is not equivalent either in theory or practice to requiring proportional representation.

Moreover, arithmetic and demographic constraints may make fully proportional representation "infeasible" in some cases. The arithmetic constraint is that the supermajority requirement may itself preclude control over a proportional number of wards. ${ }^{80}$ The demographic constraint is a function of the degree of residential integration in the polity combined with the minimal level of geographic compactness necessary for the effective operation of political districts. ${ }^{81}$ The more dispersed the minority population, the less likely that full proportional control will be possible. If, to take an extreme case, the black population of a city that is forty percent black were spread evenly throughout the city, it would be impossible to construct contiguous black-majority districts, let alone supermajority districts. $^{82}$ The standard for evaluating legislative districting under this theory of section 2's guarantee of equal electoral opportunity can thus be refined and restated as follows: In a racially polarized polity, courts should hold that districting schemes in which a minority group does not possess the necessary supermajority in a proportional number of wardsunless demographically or arithmetically infeasible-violate section 2 .

Although central to the application of section 2 to legislative districting, the supermajority concept is not without costs. But the costs are, on the

78. Turnout and registration figures should be calculated across time periods of considerable length so that they do not reflect poor organization, etc., except where it is endemic, and thus likely itself to be a legacy of discrimination.

79. Despite the creation of two "safe" districts in Brooklyn after United Jewish Orgs. v. Carey, 430 U.S. 144 (1977), the black community failed to elect a candidate of its choice. The same is often true, at least at first, in redrawn districts in the Deep South.

80. Even where the demographic factors permit a proportional number of majority-black wards to be constructed, the minority population might not be sufficiently concentrated to create as many supermajority wards as would be appropriate.

81. Since the Voting Rights Act is only a transitional stage toward full integration of minorities into American politics, it is important that the development of minority political organization not be thwarted. Compact, contiguous districts facilitate "political organization, electoral campaigning, and constituent representation." Karcher v. Daggett, 103 S. Ct. 2653, 2673 (1983) (Stevens, J., concurring).

82. At the other extreme, in Chicago in $1970,77.7 \%$ of the black population lived in census tracts $90 \%$ or more black, and $93.9 \%$ lived in tracts $50 \%$ or more black. U.S. CoMM'N ON CIVIL RIGHTS, Twenty Years After Brown: Equal Opportunity In Housing, 128-29 (1975) (1970 census data). 
whole, less than frequently supposed. The use of safe districts has been condemned for disenfranchising those "living in a district made safe for others" and affording out-of-district minorities only virtual representation. ${ }^{83}$ In fact, safe districts are premised on a group theory of electoral opportunity, as is section 2 generally. The application of this theory necessarily affects both out-of-district minorities and in-district nonminorities. While a group theory constitutes a compromise of the traditional American approach to representation, it is one that the Supreme Court has accepted in this context. ${ }^{84}$ More basically, one must question whether the "traditional approach" is appropriate in the face of racial politics and racial disparities. ${ }^{85}$

It has also been noted that the retention of legislative districting instead of, for example, resort to a cumulative voting system, limits relief to only a few groups. ${ }^{88}$ The problem of choosing beneficiary groups is overstated; both the Voting Rights Act and the Fifteenth Amendment provide guides for this choice. ${ }^{87}$ The more fundamental issue is the decision to address the exclusion of blacks from the political system independent of a broader assault on the underpinnings of the system. This decision rests on an empirical judgment that the experience of blacks in American electoral politics is anomolous, rather than paradigmatic. ${ }^{88}$ The pluralist model of shifting alliances and coalitions ${ }^{89}$ has never, in fact, applied to blacks in American politics. ${ }^{80}$

83. Note, Alternative Voting Systems as Remedies for Unlawful At-Large Systems, 92 YALE L.J. 144, 147 (1982).

84. United Jewish Orgs. v. Carey, 430 U.S. at 166 (White, J.) ("[A]s long as whites in Kings County, as a group, were provided with fair representation, we cannot conclude that there was a cognizable discrimination against whites or an abridgement of their right to vote on the grounds of race."); see also Fullilove v. Klutznick, 448 U.S. 448, 483 (1980) (Burger, C.J.) ("a state may employ racial criteria that are reasonably necessary to assure compliance with federal voting rights legislation"). More broadly, the Court has held inviolate any state plan that recognizes group political power, and "undertakes . . . through districting, [to] provide a rough sort of proportional representation in the legislative halls of the State." Gaffney v. Cummings, 412 U.S. 735, 754 (1973).

85. In any event, alternative voting systems such as cumulative voting or proportional representation are no more consistent with the American tradition. See supra note 8.

86. See Note, supra note 83, at 146-47 (safe districting "effectively guarantees some groups a voice while denying other groups the possibility of effective participation" without any principled basis for choosing among the groups).

87. The Fifteenth Amendment reads, in relevant part: "The right of citizens of the United States to vote shall not be denied or abridged by the United States or by any State on account of race, color, or previous condition of servitude." U.S. CoNST. amend. XV, \& 1. See Note, supra note 69, at 576 (arguing for Fifteenth Amendment basis for claiming potential proportional representation of racial groups).

88. See Cover, The Origins of Judicial Activism in the Protection of Minorities, 91 Yale L.J. 1287, 1301-03 (1982) (racial minorities, unlike religious or national minorities, have historically been excluded from the political arena).

89. The classic text of this pluralist model is R. DAHL, Who Governs? (1961). For a more recent exposition of this world view by a former student of Dahl, see N. Polsby, Community Power and Political Theory (2d rev. ed. 1980).

90. See J. Ely, Democracy AND Distrust 135 (1980) ("the single example of how our society 
Finally, some commentators argue that safe districting, like all forms of affirmative action, damages the "fairness and integrity of the political process." ${ }^{21}$ Their concern with fairness is particularly appropriate here because voting is central to the political process and is itself a protected right. ${ }^{92}$ The remedy proposed here, however, respects the existing political process and falls short of guaranteeing electoral outcomes. More fundamentally, the issue of fairness is a function of perspective. While the costs imposed by affirmatively gerrymandered districts are real and nontrivial, they pale in comparison with the alternative: nothing less than a society where political power is perpetually stratified along racial lines. ${ }^{93}$ This is precisely the evil which section 2 was designed to combat.

has treated its black minority . . . is more than sufficient to prove" that pluralist model does not always work); see also Cover, supra note 88, at 1296 ("Discrete and insular' minorities are not simply losers in the political arena, they are perpetual losers."). If, on the other hand, blacks were more the paradigm than the anomoly, a more wholesale response would be appropriate. For an argument that starts from this premise and advocates the adoption of a pure proportional representation system, see Note, The Constitutional Imperative of Proportional Representation, 94 YALE L.J. 163 (1984).

91. See Howard \& Howard, supra note 76, at 1654.

92. This protection extends far enough even to shield voters' use of invidious distinctions. See Marshall v. Edwards, 582 F.2d 927, 936 (5th Cir. 1978) (use of race in voting has not been prohibited). But see United Jewish Orgs. v. Carey, 430 U.S. at 167 (White, J.) (state is not "powerless to minimize the consequences of racial discrimination by voters").

93. Some might claim that perpetuation of racial polarization would itself be a cost of $\S 2$ as here defined. The argument is that official recognition of racial polarization and the construction of "segregated" districts would function to exacerbate the existing levels of polarization by heightening race consciousness. Cf. Fullilove v. Klutznick, 448 U.S. 448, 532 (1980) (Stewart, J., dissenting) ("[B]y making race a relevant criterion once again in its own affairs the Government implicitly teaches the public that the apportionment of rewards and penalties can legitimately be made according to race ... and that people can, and perhaps should, view themselves and others in terms of their racial characteristics."). This objection, while not without force, fails to note that safe districting promotes integration in legislative bodies, thus overcoming centuries of exclusion. Moreover, its implicit counterfactual-that without safe districting, racial polarization will subside-is untenable. The refusal to redress the continuing subordination of blacks in American politics is more likely to increase conflict. An alternative outcome, equally unacceptable, is that alienation and anomie will cause blacks to completely remove themselves from politics. Thus, the relevant question to be asked about the costs of safe districting is: compared to what?

Furthermore, as black political organizations mature and proliferate, the necessary supermajorities will decline and political districts will be able to become more integrated. The real obstacle to this is residential segregation, which has been a cause, but not an effect, of political district lines.

At the most basic level, it should not be forgotten that the relative harms of violation and remedy were weighed by the Congress when it amended $\S 2$. As the three-judge court in Gingles $z$. Edmisten explained:

Congress necessarily took into account and rejected as unfounded, or assumed as outweighed, . .. the risk that creating "safe" black-majority single-member districts would perpetuate racial ghettos and racial polarization in voting behavior; . . . and the fundamental risk that the recognition of "group voting rights" and the imposing of affirmative obligation upon government to secure those rights by race-conscious electoral mechanisms was alien to the American political tradition.

No. 81-803-CIV-5, slip op. at 20-21 (E.D.N.C. Jan. 27, 1984) (footnotes omitted). 


\section{Racial Gerrymandering}

\section{Applying Section 2 to Racial Gerrymandering}

Substantive guarantees of procedurally defined outcomes present conceptual problems of proof which do not arise under an intent test or a proportional representation model. The difficulty lies in measuring opportunity from the perspective of the minority group, rather than, as under an intent test, from that of the legislator. The Zimmer factors are not well suited for this task either, particularly in the context of racial gerrymandering. ${ }^{94}$ This section suggests a different procedure for proving violations of section 2 .

The language of section 2 suggests that "[t]he extent to which members of a protected class have been elected to office" is one important factor. ${ }^{95}$ But both the legislative and judicial history make it plain that "plaintiffs [have] to prove more than" mere disparity between population proportion and representation in the legislature..$^{98}$ This follows as well from the theory articulated above, since it is only in the context of racial polarization that racial vote dilution is a meaningful threat. ${ }^{97}$ Together, however, these two factors-disparity and racial polarization-should be sufficient to raise the presumption that proportional electoral opportunity does not exist, ${ }^{98}$ and to shift the burden of proof to defendants. Consistent with the theory of equal electoral opportunity, defendants could rebut this presumption by showing that the failure to achieve proportionality was due either to non-racially based handicaps, ${ }^{90}$ or to arithmetic or demographic constraints. ${ }^{100}$

There are two reasons for shifting the burden of proof after the prima

94. See supra pp. 196-98.

95. 42 U.S.C. \$ 1973 (1982). See also Howard \& Howard, supra note 76, at 1624 ("The legislative history also indicates that the lack of proportional representation will be the most important factor in the determination of a violation ....".").

For the purposes of the standard presented here, the candidate/representative need only be minority-supported, not necessarily a member of the minority group. As Blacksher and Menefee explain: "Receipt of the racial minority's bloc support would be the best, and necessary, indication that a candidate is identified with the minority's particular interests." Blacksher \& Menefee, supra note 23 , at 59 .

96. Senate RePort, supra note 10, at 23. See supra pp. 190-91. See also Blumstein, supra note 13, at 703 ("A plaintiff should not prevail by the mere showing of representational disparity.").

97. See supra p. 199.

98. See Note, The Constitutional Significance of the Discriminatory Effects of At-Large Elections, 91 YALE L.J. 974, 975, 989, 994 (1982) (either racially polarized voting or lack of proportional outcomes "raise[s] a presumption" of unconstitutional effect; together, "these conditions conclusively prove the existence of discriminatory effect"). $C f$. United States v. Texas Educ. Agency, 467 F.2d 848, 873 (5th Cir. 1972) (en banc) (Wisdom, J., for six judges) ("When the figures speak so eloquently, a prima facie case of discrimination is established.") (discussing racial composition of faculty).

99. See supra pp. 201-02. Defendants would show that minority-supported candidates failed to run, or lost, in districts in which the (polity-wide) supermajority was adequate.

100. See supra p. 202. Defendants would demonstrate that the degree of residential integration or the size of the supermajority required is such that proportional minority control is not feasible without violating the compactness requirements. The level of tolerance for deviations from proportionality would be a function of the geographic dispersion of the minority. See Note, supra note 69, at 601 . 
facie showing. First, as an empirical matter, the inference drawn from disproportionate outcomes where race is a salient political factor is likely to be correct. ${ }^{101}$ Indeed, where such disproportionate outcomes occur, the Fifth Circuit has held that without evidence to the contrary, "a court may not simply attribute present disproportions to lack of interest or apathy on the part of blacks." ${ }^{\text {102 }}$ The presence of racial polarization suggests that past discrimination has present effects.

Second, in the presence of racial disparities and racial politics, it is preferable that the burden of the unproven case fall on the state: better to require needless redistricting than to permit a violation to remain unremedied. ${ }^{103}$ Our concern with racial justice and eradicating the effects of past, pervasive discrimination outweighs the competing interests of federalism and administrative convenience. This relative valuation is made by the Voting Rights Act itself, which compels all jurisdictions with a history of low minority-voter participation and discriminatory registration tests to preclear all proposed voting or electoral changes with the United States Attorney General or the United States District Court for the District of Columbia. ${ }^{104}$ The prima facie showing under section 2 should likewise function to shift the inertia away from the status quo.

Since shifting the burden does not resolve the case, it also does not redefine the right in terms of outcomes. Shifting the burden does not, therefore, smuggle a lower standard of proof into section 2 . For even if plaintiffs establish the threshold facts of racial polarization and disparity in electoral success, defendants may disprove the presumed fact-inequality of opportunity. Justifications, however, are irrelevant. Unless the defendant can show that as a matter of fact the plaintiffs are not denied equal electoral opportunity, the plaintiff prevails.

\section{The Results Test Compared}

The preceding section offers a plausible interpretation of section 2, but not one that is in any way compelled by the text. The following section

101. A similar inference has been drawn from disproportionate racial composition in schools. See United States v. Jefferson County Bd. of Educ., 372 F.2d 836, 888 (5th Cir. 1966) ("[A] gross discrepancy. . . raises an inference that the school plan is not working . . . ."); $c f$. Fiss, The Fate of an Idea Whose Time Has Come: Antidiscrimination Law in the Second Decade After Brown v. Board of Education, 41 U. CHI. L. Rev. 742, 762 (1974) ("[R]acial statistics were used . . . to shift burdens of proof, and even .... to define the terms of compliance ....").

102. Cross v. Baxter, 604 F.2d 875, 882 (5th Cir. 1979).

103. Cf. Addington v. Texas, 441 U.S. 418,423 (1979) (a standard of proof "serves to allocate the risk of error between the litigants and to indicate the relative importance attached to the ultimate decision").

104. Section 5 of the Voting Rights Act, 42 U.S.C. § 1973c (1982). See Note, Getting Results Under Section Five of the Voting Rights Act, 94 YALE L.J. 139, 156-57 (1984) (explaining congressional rationale for shifting burden of proof away from minority voters in cases brought under §§ 4 and 5 of Voting Rights Act). 


\section{Racial Gerrymandering}

will demonstrate the superiority of the interpretation advanced here over competing theories of proportional representation and intent.

The focus on "results" contained in section 2 is both distinct from, and more appropriate than, defining rights in terms of substantive entitlements or negative process guarantees. First, as noted above, the Voting Rights Act stops short of guaranteeing any particular electoral outcomes. Not only is such an approach disclaimed by the statutory language, ${ }^{105}$ it is also inconsistent with our notions of political democracy. Any scheme that entirely predetermined the outcomes of elections would obliterate their significance. In the same way, a system that necessarily elected a fixed percentage of black and white representatives would significantly constrain the choices of all citizens, and would inevitably perpetuate racial polarization. In consequence, the political autonomy of minority citizens would be denied by the very Act intended to protect it. Under section 2's guarantee, however, each ward or district can choose to be represented by a politician of any race or political persuasion. The core concern of section 2 is not that minorities necessarily be candidates, but that minorities control their representatives. Whatever instrumental value controlling representatives might have, there is an intrinsic value to a voice in the legislature.

Second, the results test provides more than freedom from purposeful discrimination, as in the prevailing constitutional standard. ${ }^{108}$ The violation under section 2 is defined in terms of conditions rather than actions, and one therefore compares actual with potential states rather than invidious with acceptable motives. The constitutional intent test fails to provide adequate safeguards against vote dilution since it poses the wrong question. It "diverts the judicial [inquiry] . . . from the crucial question of whether minorities have equal access to the electoral process to a historical question of individual motives." 107

Even on its own terms the intent test could not work for racial gerrymandering. Quite often in redistricting, legislators are concerned with preserving incumbency. While this has been held not to be per se invidious, ${ }^{108}$ the effect of such motivation ceases to be benign when its price is

105. 42 U.S.C. $\S 1973$ (1982) ("Provided, That nothing in this section establishes a right to have members of a protected class elected in numbers equal to their proportion in the population.").

106. See Rogers v. Lodge, 458 U.S. 613, 621 (1982) (a finding of unconstitutional vote dilution under either the Fourteenth or Fifteenth Amendment must be predicated on "a determination of discriminatory intent").

107. Senate RepoRt, supra note 10, at 16. Moreover, as the Court in Palmer v. Thompson, 403 U.S. 217, 225 (1971), explained: "It is difficult or impossible for any court to determine the 'sole' or 'dominant' motivation behind the choices of a group of legislators."

108. Mississippi v. United States, 490 F. Supp. 569, 583 (D.D.C. 1979) ("It is not improper . . for a legislative body to consider incumbency in fashioning a reapportionment plan . . . "). Cf. Karcher v. Daggett, 103 S.Ct. 2653, 2663 (1983) ("avoiding contests between incumbent Representatives" is a legitimate basis for deviating from perfect population equality). 
the dilution of minority voting strength. As so often happens, "the requirements of incumbency are so closely intertwined with the need for racial dilution that an intent to maintain a safe, primarily white, district . . . is virtually coterminus with a purpose to practice racial discrimination."109 In any event, because "an accidental gerrymander can be just as devastating as one which emanates from a secret chart room,"110 the broader guarantees of the results test are needed.

Moreover, the results test of section 2 embraces more than the individual notion of causation associated with the intent standard. ${ }^{111}$ It recognizes that structures and institutions may also disadvantage determinate groups and thus interfere with procedural fairness. In so doing, the results test better comports with the notion central to a commitment to racial justice: that law should redress not only ongoing discrimination, but also the institutionalized and cumulative effects of past purposeful, legalized, and constitutionalized discrimination. The absence of racial animus is but one element of race neutrality.

\section{Conclusion}

Unlike the Zimmer factors, the test proposed here relates directly to the right in question, and specifically addresses the problem of racial gerrymandering. Most important, it offers the courts an objective, external standard-supermajorities in a proportional number of wards-by which to evaluate the adequacy of alternative districting plans. Absent such a standard, claims of racial gerrymandering will continue to be adjudicated in an ad hoc and inconsistent manner. The right to equal electoral opportunity must not vary according to the political ideology of the trial judge.

The results test of section 2 , with its broadened conception of equality of opportunity, promises minority groups full integration into American electoral politics. The standards articulated in this Note are designed to facilitate challenges to districting systems that deny this vision.

-Howard M. Shapiro

109. Rybicki v. State Bd. of Elections, 574 F. Supp. 1082, 1109 (N.D. Ill. 1982). See also Major v. Treen, 574 F.Supp. 325, 355 (E.D. La. 1983) (three-judge court) (pragmatic political considerations "may not serve to protect incumbents by imposing an electoral scheme which splinters a geographically concentrated black populace within a racially polarized parish, thus minimizing the black citizenry's electoral participation").

110. Dixon, supra note 39 , at 30 .

111. See Freeman, Legitimizing Racial Discrimination Through Antidiscrimination Lau: A Critical Review of Supreme Court Doclrine, 62 MinN. L. REv. 1049, 1054-56 (1978) (the intent standard "presupposes a world composed of atomistic individuals"). 